\title{
Reducing methane production with corn oil and calcium sulfate: Responses on whole-animal energy and nitrogen balance in dairy cattle
}

\author{
J. V. Judy, ${ }^{1}$ G. C. Bachman, ${ }^{2}$ T. M. Brown-Brandl, ${ }^{3}$ S. C. Fernando, ${ }^{1}$ K. E. Hales, ${ }^{3}$ P. S. Miller, ${ }^{1}$ R. R. Stowell, ${ }^{1}$ \\ and P. J. Kononoff ${ }^{1 *}$ \\ ${ }^{1}$ Department of Animal Science, University of Nebraska, Lincoln 68583 \\ ${ }^{2}$ Department of Biological Science, University of Nebraska, Lincoln 68583 \\ ${ }^{3}$ USDA, Agricultural Research Service, US Meat Animal Research Center, Clay Center, NE 68933
}

\section{ABSTRACT}

The addition of fat and calcium sulfate to diets fed to ruminants has resulted in a reduction in methane production, but the effects on energy balance have not been studied. A study using indirect calorimetry and 16 multiparous (8 Holstein and 8 Jersey; $78 \pm 15 \mathrm{~d}$ in milk; mean \pm standard deviation) lactating dairy cows was conducted to determine how mitigating methane production by adding corn oil or calcium sulfate to diets containing reduced-fat distillers grains affects energy and nitrogen balance. A replicated $4 \times 4$ Latin square design with 35 -d periods ( $28 \mathrm{~d}$ of adaption and 4 $\mathrm{d}$ of collections) was used to compare 4 different dietary treatments. Treatments were composed of a control $(\mathrm{CON})$ diet, which did not contain reduced-fat distillers grain and solubles (DDGS), and treatment diets containing 20\% (dry matter basis) DDGS (DG), 20\% DDGS with $1.38 \%$ (dry matter basis) added corn oil (CO), and 20\% DDGS with $0.93 \%$ (dry matter basis) added calcium sulfate (CaS). Compared with CON, dry matter intake was not affected by treatment, averaging $29.6 \pm 0.67 \mathrm{~kg} / \mathrm{d}$. Milk production was increased for diets containing DDGS compared with CON (26.3 vs. $27.8 \pm 0.47 \mathrm{~kg} / \mathrm{d}$ for CON vs. DDGS, respectively), likely supported by increased energy intake. Compared with CON, energy-corrected milk was greater in DG and $\mathrm{CO}(30.1$ vs. $31.4,31.7$, and $31.0 \pm 0.67 \mathrm{~kg} / \mathrm{d}$ for CON, DG, CO, and CaS, respectively). Compared with CON, the addition of calcium sulfate and corn oil to diets containing DDGS reduced methane production per $\mathrm{kg}$ of dry matter intake $(22.3,19.9$, and $19.6 \pm$ $0.75 \mathrm{~L} / \mathrm{kg}$ per d for CON, CO, and CaS, respectively). Similarly, methane production per kilogram of energycorrected milk was reduced with the addition of calcium sulfate and corn oil to diets containing DDGS (14.2, 12.5 , and $12.4 \pm 0.50 \mathrm{~L} / \mathrm{kg}$ per $\mathrm{d}$ for $\mathrm{CON}, \mathrm{CO}$, and

Received February 9, 2018.

Accepted November 7, 2018.

*Corresponding author: pkononoff $2 @ u n l . e d u$
CaS, respectively). Compared with $\mathrm{CON}$ and $\mathrm{CaS}$, the intake of digestible energy was greater for $\mathrm{DG}$ and $\mathrm{CO}$ treatments $(57.7,62.1,62.0$, and $59.0 \pm 1.38 \mathrm{Mcal} / \mathrm{d}$ for CON, DG, CO, and CaS, respectively). Intake of metabolizable energy was greater in all treatments containing DDGS compared with CON (50.5 vs. 54.0 $\pm 1.08 \mathrm{Mcal} / \mathrm{d}$ for CON vs. DDGS, respectively). Net balance (milk plus tissue energy) per unit of dry matter was greater in CO (containing DDGS and oil) than $\mathrm{CON}$ (1.55 vs. $1.35 \pm 0.06 \mathrm{Mcal} / \mathrm{kg}$ for $\mathrm{CO}$ vs. $\mathrm{CON}$, respectively). Tissue energy was greater in DG and CO compared with CON (6.08, 7.04, and $3.16 \pm 0.99$ $\mathrm{Mcal} / \mathrm{d}$ for DG, CO, and CON, respectively. Results of this study suggest that the addition of oil and calcium sulfate to diets containing DDGS may be a viable option to reduce methane production and in the case of oil also improve net energy balance in lactating dairy cows.

Key words: dairy cow, dried distillers grains and solubles, energy, methane

\section{INTRODUCTION}

Lactating dairy cattle produce approximately 400 to $600 \mathrm{~L} / \mathrm{d}$ of $\mathrm{CH}_{4}$ (Beauchemin et al., 2008; Chase, 2014). According to the Environmental Protection Agency (2010), compared with $\mathrm{CO}_{2}$, the greenhouse warming potential of $\mathrm{CH}_{4}$ is 28 to 36 times more potent (IPCC, 2013). The dairy supply chain contributes 1.9 to $2.2 \%$ to the total greenhouse gas emissions in the United States (Thoma et al., 2013; Chase, 2014). Ruminants produce approximately $25 \%$ of the total enteric $\mathrm{CH}_{4}$ production of which dairy cattle contribute approximately $24.8 \%$ of enteric $\mathrm{CH}_{4}$ production or $0.54 \%$ of the greenhouse gas total (Chase, 2014). In 2009, the Innovation Center for US Dairy set a goal to reduce total greenhouse gas emissions by dairy operations by $25 \%$ by the year 2020 (Innovation Center for US Dairy, 2009). Given the contribution of ruminants to total $\mathrm{CH}_{4}$ production, ample opportunities exist to reduce $\mathrm{CH}_{4}$ production and should be investigated further. 
Many strategies have been devised to reduce $\mathrm{CH}_{4}$ production and they can be broadly categorized into 3 main methods: nutritional or feed management, modification the rumen environment to directly inhibit methanogenesis, and management practices that improve productive efficiencies (Knapp et al., 2014). Dietary strategies includes the addition of ionophores, fats, altering the forage-to-concentrate ratio, and using alternative hydrogen sinks in the rumen (Johnson and Johnson, 1995; Knapp et al., 2014). The use of distillers grains with solubles (DDGS) as a feed has increased and this feed may also reduce $\mathrm{CH}_{4}$ production. Benchaar et al. (2013) replaced corn and soybean meal with DDGS and observed a $9 \%$ reduction in $\mathrm{CH}_{4}$ per unit of ECM. Similarly, Foth et al. (2015) fed reduced-fat DDGS to lactating dairy cows and observed a $7 \%$ decrease. These studies suggest that feeding DDGS may be an effective way to reduce $\mathrm{CH}_{4}$ production. Johnson and Johnson (1995) suggested that by-products such as DDGS have highly digestible NDF and produce one-half to onethird the $\mathrm{CH}_{4}$ compared with forages with similar DM digestibility. Lipid supplementation is an additional method that may be used to reduce $\mathrm{CH}_{4}$ production in ruminants. Hales et al. (2017) fed increasing concentrations of corn oil in diets fed to growing beef steers and observed a linear decrease in $\mathrm{CH}_{4}$ production, and $\mathrm{CH}_{4}$ energy by approximately $30 \%$ when $6 \%$ of the diet DM was corn oil. Utilization of sulfate has reduced $\mathrm{CH}_{4}$ production. When fed to sheep, supplemental sulfate reduced $\mathrm{CH}_{4}$ production by $16 \%$ (van Zijderveld et al., 2010). The addition of fat and sulfur to DDGS may serve as a practical method to consistently reduce $\mathrm{CH}_{4}$ production in lactating dairy cattle.

Environmental concerns are not the only reason $\mathrm{CH}_{4}$ production is important in the dairy industry. Methane production may have a negative effect on ME available for production and reduce overall efficiency (Gill et al., 2010; Hynes et al., 2016). Energetic losses from $\mathrm{CH}_{4}$ production are believed to range from 2 to $12 \%$ (Johnson and Johnson, 1995). It has also been suggested that a $25 \%$ reduction in $\mathrm{CH}_{4}$ production in cattle could translate into $75 \mathrm{~g} / \mathrm{d}$ of BW gain in beef cattle (Nkrumah et al., 2006). Overall, because $\mathrm{CH}_{4}$ production represents an energetic loss for cattle, reducing $\mathrm{CH}_{4}$ production could result in the repartition of more energy toward production processes. However, research is limited exploring how these mitigation techniques affect whole-animal energy and nitrogen balance and the digestibility of the diet in lactating dairy cattle. Therefore, the overall objective of this study was to determine the effects of manipulating the diet with proposed $\mathrm{CH}_{4}$ reduction techniques specifically DDGS, corn oil, and calcium sulfate. Specific objectives were to determine $\mathrm{CH}_{4}$ production and determine the ef- fects of these $\mathrm{CH}_{4}$ reduction techniques on whole-body energy and nitrogen utilization in dairy cows. It was hypothesized that the additions of DDGS, corn oil, and sulfate would reduce $\mathrm{CH}_{4}$ production and increase energy balance without negatively affecting production in lactating dairy cows.

\section{MATERIALS AND METHODS}

Sixteen multiparous (8 Holstein and 8 Jersey; 78 \pm 15 DIM; mean \pm SD) lactating dairy cows with a BW averaging $593.8 \pm 15.7$ and $428.3 \pm 15.7 \mathrm{~kg}$, respectively, at the beginning of the experiment were used. The objective of this study was not to determine breed difference, nor to determine the interaction between treatment and breed. All cows were housed in a temperature-controlled barn at the Dairy Metabolism Facility at the Animal Science Complex at the University of Nebraska (Lincoln) and milked at 0700 and $1800 \mathrm{~h}$ in individual tiestalls equipped with rubber mats. All animal care and experimental procedures were approved by the University of Nebraska - Lincoln Animal Care and Use Committee. At the conclusion of the last experimental period, all cows were less than 90 d pregnant and as a result energy committed to fetal development was minimal.

The experimental design was a quadruple-replicated $4 \times 4$ Latin square. Cows were blocked by breed and randomly assigned to 1 of the 4 dietary treatments (Kononoff and Hanford, 2006). Treatments were the control $(\mathbf{C O N})$ diet, which did not contain reduced-fat DDGS, and treatment diets containing 20\% (DM basis) DDGS (DG), 20\% DDGS with 1.38\% (DM basis) added corn oil (CO), and 20\% DDGS with $0.93 \%$ (DM basis) added calcium sulfate (CaS), according to Kononoff and Hanford (2006). Animals were blocked into each square by breed and milk production. Treatments alternated over 4 experimental periods and measurements were collected on each animal consuming each dietary treatment. The study was conducted with a total of 4 experimental periods, each being $32 \mathrm{~d}$ in duration. Each period included $28 \mathrm{~d}$ for ab libitum diet adaptation, targeting approximately $5 \%$ feed refusal during that time, followed by $4 \mathrm{~d}$ of collection with $95 \%$ ad libitum feeding to reduce the amount of refusals.

Diets containing DDGS replaced all soybean meal and a portion of ground corn with DDGS (Table 1). Soybean meal was completely replaced by DDGS as well as a portion of the ground corn in the diets containing DDGS. Additional corn was removed from the diet when $\mathrm{CO}$ or $\mathrm{CaS}$ were added to the diets. All other ingredients were formulated to have similar inclusion rates (Table 1). The Cornell-Penn-Miner Dairy model (Boston et al., 2000) was used to balance diets. The 
Table 1. Chemical composition and analysis of treatment diets formulated to reduce methane in lactating dairy cattle

\begin{tabular}{|c|c|c|c|c|}
\hline \multirow[b]{2}{*}{ Item } & \multicolumn{4}{|c|}{ Treatment $^{1}$} \\
\hline & $\mathrm{CON}$ & DG & $\mathrm{CO}$ & $\mathrm{CaS}$ \\
\hline \multicolumn{5}{|l|}{ Ingredient, $\%$ of DM } \\
\hline Corn silage & 29.8 & 29.8 & 29.8 & 29.8 \\
\hline Alfalfa hay & 26.6 & 26.6 & 26.6 & 26.6 \\
\hline Brome hay & 2.57 & 2.57 & 2.57 & 2.56 \\
\hline Ground corn & 21.8 & 12.9 & 11.5 & 12.6 \\
\hline Ground soybean hulls & 0.55 & 0.55 & 0.55 & 0.55 \\
\hline DDGS & - & 20.0 & 20.0 & 20.0 \\
\hline Soybean meal & 11.0 & - & - & - \\
\hline Expellers soybean meal ${ }^{2}$ & 4.59 & 4.59 & 4.59 & 4.59 \\
\hline Bloodmeal & 0.46 & 0.46 & 0.46 & 0.46 \\
\hline Corn oil & - & - & 1.38 & - \\
\hline Calcium carbonate & 0.75 & 0.75 & 0.75 & 0.18 \\
\hline Calcium sulfate & - & - & - & 0.93 \\
\hline Sodium bicarbonate & 0.62 & 0.62 & 0.62 & 0.62 \\
\hline Ca-salts of LCFA ${ }^{3}$ & 0.55 & 0.55 & 0.55 & 0.55 \\
\hline Magnesium oxide & 0.24 & 0.24 & 0.24 & 0.24 \\
\hline Salt & 0.18 & 0.18 & 0.18 & 0.18 \\
\hline Trace mineral premix ${ }^{4}$ & 0.09 & 0.09 & 0.09 & 0.09 \\
\hline Vitamin premix ${ }^{5}$ & 0.09 & 0.09 & 0.09 & 0.09 \\
\hline \multicolumn{5}{|l|}{ Chemical composition $^{6}$} \\
\hline DM, $\%$ & $53.9(0.49)$ & $54.1(0.49)$ & $54.2(0.51)$ & $54.0(0.48)$ \\
\hline $\mathrm{CP}, \%$ of $\mathrm{DM}$ & $18.0(0.50)$ & $17.2(0.24)$ & $16.9(0.21)$ & $17.3(0.37)$ \\
\hline Crude fat, $\%$ of DM & $2.65(0.16)$ & $3.38(0.37)$ & $4.76(0.21)$ & $3.55(0.19)$ \\
\hline $\mathrm{ADF}, \%$ of $\mathrm{DM}$ & $22.0(0.63)$ & $23.2(0.99)$ & $23.3(0.81)$ & $23.5(0.91)$ \\
\hline NDF, \% of DM & $31.5(1.00)$ & $34.7(1.68)$ & $35.1(0.75)$ & $35.6(0.45)$ \\
\hline Lignin, \% of DM & $4.20(0.12)$ & $4.52(0.20)$ & $4.64(0.24)$ & $4.52(0.19)$ \\
\hline Ash, \% of DM & $7.79(0.15)$ & $7.78(0.24)$ & $7.83(0.18)$ & $8.16(0.49)$ \\
\hline Starch, \% of DM & $26.9(1.62)$ & $23.2(1.41)$ & $21.9(0.72)$ & $22.4(0.65)$ \\
\hline Sulfur, \% of DM & $0.23(0.03)$ & $0.32(0.04)$ & $0.34(0.01)$ & $0.52(0.03)$ \\
\hline Gross energy, ${ }^{7} \mathrm{cal} / \mathrm{g}$ & $4,387.9(58.1)$ & $4,500.4(41.8)$ & $4,558.5(42.8)$ & $4,492.2(51.8)$ \\
\hline $\mathrm{ME}{ }^{8} \mathrm{Mcal} / \mathrm{kg}$ & 2.64 & 2.51 & 2.59 & 2.50 \\
\hline $\mathrm{NE}_{\mathrm{L}},{ }^{8} \mathrm{Mcal} / \mathrm{kg}$ & 1.70 & 1.62 & 1.67 & 1.61 \\
\hline
\end{tabular}

${ }^{1}$ Treatments: $\mathrm{CON}=$ control; $\mathrm{DG}=$ reduced-fat dried distillers grains and solubles; $\mathrm{CO}=\mathrm{DG}$ plus corn oil; $\mathrm{CaS}=\mathrm{DG}$ plus calcium sulfate.

${ }^{2}$ Soypass, LignoTech, Overland Park, KS.

${ }^{3}$ Calcium salts of long-chain fatty acids marketed as Megalac by Church \& Dwight Co. Inc., Princeton, NJ.

${ }^{4}$ Formulated to supply $2,300 \mathrm{mg} / \mathrm{kg}$ of $\mathrm{Co}, 25,000 \mathrm{mg} / \mathrm{kg}$ of $\mathrm{Cu}, 2,600 \mathrm{mg} / \mathrm{kg}$ of I, 1,000 mg $/ \mathrm{kg}$ of Fe, 150,000 $\mathrm{mg} / \mathrm{kg}$ of $\mathrm{Mn}, 820 \mathrm{mg} / \mathrm{kg}$ of Se, and $180,000 \mathrm{mg} / \mathrm{kg}$ of $\mathrm{Zn}$ in total rations.

${ }^{5}$ Formulated to supply $148,500 \mathrm{IU} / \mathrm{d}$ of vitamin A, 38,500 IU/d of vitamin D, and $902 \mathrm{IU} / \mathrm{d}$ of vitamin E in total rations.

${ }^{6}$ Values determined by Cumberland Valley Analytical Services (Hagerstown, MD); mean (SD).

${ }^{7}$ Determined from composite samples from experiment and analyzed at the University of Nebraska-Lincoln; mean (SD).

${ }^{8}$ Values formulated from Cornell-Penn-Miner dairy model (Boston et al., 2000).

TMR was mixed in a Calan Data Ranger (American Calan Inc., Northwood, NH) and fed once daily at 0900 h.

\section{Laboratory Analysis}

Individual feed ingredients were sampled (500 g) on the first day of each collection period and frozen at $-20^{\circ} \mathrm{C}$. A subsample was sent to Cumberland Valley Analytical Services Inc. (Waynesboro, PA) for complete nutrient analysis of DM (AOAC International, 2000), N (Leco FP-528 N Combustion Analyzer, Leco Corp., St. Joseph, MO), NDF (with sodium sulfite; Van Soest et al., 1991), ADF (method 973.18; AOAC International, 2000), lignin (Goering and Van Soest, 1970), starch (Hall, 2009), crude fat (2003.05; AOAC International, 2006), ash (943.05; AOAC International, 2000), and minerals (985.01; AOAC International, 2000). Total mixed rations were sampled $(500 \mathrm{~g})$ on each day of each collection period and were frozen at $-20^{\circ} \mathrm{C}$. The samples were then composited by period and treatment. A subsample was sent to Cumberland Valley Analytical Services Inc. (Waynesboro, PA) for complete nutrient analysis with the same laboratory processes as the individual feed ingredients. Particle size of the TMR was determined according to Heinrichs and Kononoff 
(2002) using the Penn State Particle Separator. Each day of the collection period before feeding, refusals were sampled and frozen at $-20^{\circ} \mathrm{C}$. The samples were composited by period and individual cow. A subsample was sent to Cumberland Valley Analytical Services Inc. (Hagerstown, MD) for analysis of DM, N, NDF (with sodium sulfite), starch, and ash, using previously discussed methods. Drinking water samples were taken on the first day of collections and sent to Midwest Laboratories Inc. (Omaha, NE) for direct metals analysis [livestock suitability water analysis; EPA method 200.7 (EPA, 1994)].

Total fecal and urine output was collected from each individual cow during the collection period for 4 consecutive days. A $137 \times 76 \mathrm{~cm}$ rubber mat (Snake River Supply, Idaho Falls, ID) was placed behind the cow to collect feces. The feces were deposited multiple times a day from the rubber mats into a large garbage container (Rubbermaid, Wooster, $\mathrm{OH}$ ) with a black garbage bag covering the top to reduce nitrogen losses before subsampling. The feces were subsampled $(4 \%$ wet basis) every day for 4 consecutive days and dried at $60^{\circ} \mathrm{C}$ in a forced-air oven for $48 \mathrm{~h}$ and then composited by cow and period before being ground to pass through a 1-mm screen (Wiley mill, Arthur H. Thomas Co., Philadelphia, PA). The ground feces samples were sent to Cumberland Valley Analytical Services Inc. (Hagerstown, MD) for nutrient analysis of DM, N, and NDF with sodium sulfide, starch, and ash, using previously described methods. Total urine was collected by inserting a 30-French Foley catheter into each cow's bladder with a stylus (Tamura et al., 2014). The balloon was inflated to $50 \mathrm{~mL}$ with physiological saline and urine drained using Tygon tubing into a plastic carboy (14.2 L; Midwest Can Co., Melrose Park, IL) behind the cow. Using the funnel spout of the plastic carboy, urine was deposited into a 55 -L plastic container 4 times a day and was acidified with $50 \mathrm{~mL}$ of $\mathrm{HCl}$ before subsampling ( $2 \%$ wet basis) and frozen at $-20^{\circ} \mathrm{C}$ every day of the collection period. Before analysis, urine was thawed and boiled to reduce the water content and increase the speed for lyophilization. To boil the urine, 2 thawed $250-\mathrm{mL}$ bottles of urine were poured into a $600-\mathrm{mL}$ beaker. Twelve urine-filled beakers were placed into a boiling water bath (Ankom Technology, Macedon, NY) underneath a hood. The water bath was turned on in the morning and off in the afternoon, for approximately $6 \mathrm{~h}$ each day, to reduce the potential of the sample being overheated and burned to reduce the potential for nitrogen loss. The remaining residue was then composited by cow and period. The brown paste was then lyophilized (VirTis Freezemobile 25ES, SP Scientific, Gardiner, NY) and analyzed. Once lyophilized, sample size was reduced using mortar and pestle for analy- sis. Urine samples were analyzed at the University of Nebraska-Lincoln laboratory for corrected DM $\left(100^{\circ} \mathrm{C}\right.$ oven for $24 \mathrm{~h}$ ), N (Leco FP-528, Leco Corp.), and gross energy (GE; Parr 6400 Calorimeter, Moline, IL).

Milk production was measured daily and milk samples were collected during both the AM and PM milking times for 4 consecutive days or d 29 to 32 of the entire period. Two tubes were collected each milking (150 $\mathrm{mL}$ ); one $50-\mathrm{mL}$ conical tube was frozen at $-20^{\circ} \mathrm{C}$ and one was preserved using 2-bromo-2-nitropropane-1,3 diol and sent to Heart of America DHIA (Kansas City, MO) and analyzed for fat, protein, lactose, SNF, MUN, and SCC using a Bentley FTS/FCM Infrared Analyzer (Bentley Instruments, Chaska, MN). The conical tube was lyophilized and then composited by cow and period to determine chemical composition. Milk samples were analyzed at the University of Nebraska-Lincoln laboratory for corrected DM, N, and GE. To determine the DM content of individual feed ingredients, TMR, refusals, feces, and urine samples were dried at $60^{\circ} \mathrm{C}$ in a forced-air oven for $48 \mathrm{~h}$ and then composited by treatment or cow and period. Milk samples were lyophilized to determine DM. Feed ingredients, refusals, and feces were ground and analyzed as previously described (with the feces) for laboratory-corrected DM and GE.

Heat production was determined through the headbox-type indirect calorimeters described by Foth et al. (2015) and Freetly et al. (2006). Before collections, 5 headboxes were used to test the rate of recovery of gas by burning $100 \%$ ethyl alcohol in the sealed headbox and comparing this measure to calculated gas concentrations. These calculations were based on weight of alcohol burned and a measured volume of gas sample. Five lamp runs were conducted. Recovery rates of $\mathrm{O}_{2}$ and $\mathrm{CO}_{2}$ averaged $101.0 \pm 0.04$ and $100.8 \pm 0.04 \%$, respectively. For each cow, a collection period of 2 consecutive 23-h intervals measured $\mathrm{O}_{2}$ consumption, and $\mathrm{CO}_{2}$ and $\mathrm{CH}_{4}$ production. The design of the headboxes allowed for feed to be placed in the bottom of the box and ad libitum access to water was available for the cows from a water bowl placed inside the headbox. Water intake was measured using a water meter (DLJ Meter, Hackensack, NJ) while each cow was inside the headbox. Within the headbox, temperature and dew point were recorded every minute for a 23 -h interval using a probe (model TRH-100, Pace Scientific Inc., Moorseville, NC) that was connected to a data logger (model XR440, Pace Scientific Inc.). Fifteen minutes before the start of the collection, the doors were closed and the motor was turned on to allow for several air turnovers before gases were collected. Line pressure was measured using a manometer (item \#1221-8, United Instruments, Westbury, NY). Barometric pressure of the room was also recorded using a barometer (Chaney 
Instruments Co., Lake Geneva, WI) and uncorrected for sea level. Total volume of gas that passed through the headbox during each run was measured using a dry gas meter (model AL425, American Meter, Horsham, PA). From the headbox, continuous amounts of outgoing and incoming air were diverted to 2 different collection bags $(61 \times 61 \mathrm{~cm}$ LAM-JAPCON-NSE, 44 L; PMC, Oak Park, IL) using glass tube rotameters (model 1350E Sho-Rate "50," Brooks Instruments, Hatfield, PA). Collection bags with gas samples inside were analyzed (Emerson X-stream 3-channel analyzer, Solon, $\mathrm{OH})$ at the US Meat Animal Research Center according to Nienaber and Maddy (1985). Measurements collected from the $2 \mathrm{~d}$ were averaged to obtain one combined value. Heat production was estimated through calculation of $\mathrm{O}_{2}$ consumption, and $\mathrm{CO}_{2}$ and $\mathrm{CH}_{4}$ production with correction for urinary $\mathrm{N}$ loss according to Brouwer (1965; Equation 1). The gaseous products were reported in liters and the mass of urinary $\mathrm{N}$ in grams. Respiratory quotient was calculated using the ratio of $\mathrm{CO}_{2}$ produced to the $\mathrm{O}_{2}$ consumed and was not corrected for nitrogen. Volume of $\mathrm{CH}_{4}$ produced was multiplied by a constant of $9.45 \mathrm{kcal} / \mathrm{L}$ to estimate the amount of energy formed from the gaseous products. Energy balance was calculated for each cow and adjusted for excess $\mathrm{N}$ intake according to Freetly et al. (2006) using the following equations:

$$
\begin{aligned}
\text { heat production } & (\mathbf{H P} ; \mathrm{Mcal} / \mathrm{d})=3.866 \times \mathrm{O}_{2}(\mathrm{~L}) \\
+1.200 \times & \mathrm{CO}_{2}(\mathrm{~L})-0.518 \times \mathrm{CH}_{4}(\mathrm{~L}) \\
& -1.431 \times \mathrm{N}(\mathrm{g})
\end{aligned}
$$

$\operatorname{ME}(\mathrm{Mcal} / \mathrm{d})=$ gross energy intake $(\mathrm{Mcal} / \mathrm{d})$

- fecal energy (Mcal/d) - urinary energy (Mcal/d)

- methane energy (Mcal/d),

recovered energy $(\mathbf{R E} ; \mathrm{Mcal} / \mathrm{d})=\mathrm{ME}-\mathrm{HP}$,

tissue energy $(\mathbf{T E} ; \mathrm{Mcal} / \mathrm{d})=$

$$
\text { RE - milk energy (Mcal/d), }
$$

TE in protein $(\mathrm{g} / \mathrm{d})=(\mathrm{N}$ balance $\mathrm{g} / \mathrm{d})$

$$
\begin{aligned}
& \times(5.88 \mathrm{~kg} \text { of protein } / \mathrm{kg} \text { of } \mathrm{N}) \\
& \times(5.7 \mathrm{Mcal} / \mathrm{kg} \text { of protein }) / 1,000
\end{aligned}
$$

Using the REG procedure of SAS (SAS Institute Inc., Cary, NC), ME for maintenance was calculated by regression of $\mathrm{RE}$ on $\mathrm{ME}$ and is the ME at zero RE as illustrated in Figure 1. Tissue energy in protein describes the energy used for tissue protein synthesis (Equation $5)$.

Journal of Dairy Science Vol. 102 No. 3, 2019

\section{Statistical Analysis}

Data were analyzed using the MIXED procedure of SAS (SAS Institute Inc.). Treatment and period were modeled as fixed effects, whereas cow within square was modeled as a random effect. No breed $\times$ treatment interaction was observed for any measureable item, and as such, treatment means contain both Holstein and Jersey cattle data. The LSMEANS option was used to generate least squares means of treatments listed in this study. Significance was declared at $P \leq 0.05$ and trends at $0.05<P \leq 0.10$. The DIFF option was used to separate means if the $P$-value associated with the overall treatment mean was $\leq 0.10$.

\section{RESULTS AND DISCUSSION}

\section{Diet Composition}

Chemical composition of dietary treatments and feed ingredients are presented in Tables 1 and 2. Based on the formulations, the CON treatment had a slightly greater estimated $\mathrm{NE}_{\mathrm{L}}$ content and protein content compared with treatments containing DDGS (Table 1). Concentrations of crude fat were higher in treatments containing DDGS, and as expected, the CO treatment contained the greatest concentration of fat (Table 1). Although fat content varied, all treatments contained fat at less than the recommended maximum inclusion of $7 \%$ (NRC, 2001). Sulfur was greater in treatments containing DDGS, and as expected, CaS contained the highest concentration of sulfur $(0.23,0.32,0.34$, and $0.52 \%$ of dietary DM for CON, DG, CO, and CaS, respectively). The sulfur concentration in the CaS treatment exceeded the recommended concentrations from the NRC (2001) of $0.4 \%$ of dietary DM. However, the recommendation with cattle consuming a diet with at least $40 \%$ forage is $0.5 \%$ (NRC, 2005). In the current study, forage was included at $60 \%$, and therefore, we believed the sulfur would not be problematic, but also could potentially elicit a reduction in $\mathrm{CH}_{4}$ production. Particle size of the TMR was not different for treatments (Table 3). For the CON treatment, 4.81, 25.2, 50.9 , and $18.9 \%$ remained for the $>19.0 \mathrm{~mm}, 8.0 \mathrm{~mm}$, $1.18 \mathrm{~mm}$, and pan $(<1.18 \mathrm{~mm})$, respectively. For the DDGS treatments, $5.38,25.2,45.5$, and $23.9 \%$ remained for the $>19.0 \mathrm{~mm}, 8.0 \mathrm{~mm}, 1.18 \mathrm{~mm}$, and pan $(<1.18$ $\mathrm{mm})$, respectively.

\section{Dry Matter Intake, Milk Production, and Composition}

Inclusion of DDGS has been reported to be an effective feed ingredient in lactating dairy cattle diets without negatively affecting production performance (Castillo-Lopez et al., 2014). For example, DMI has 


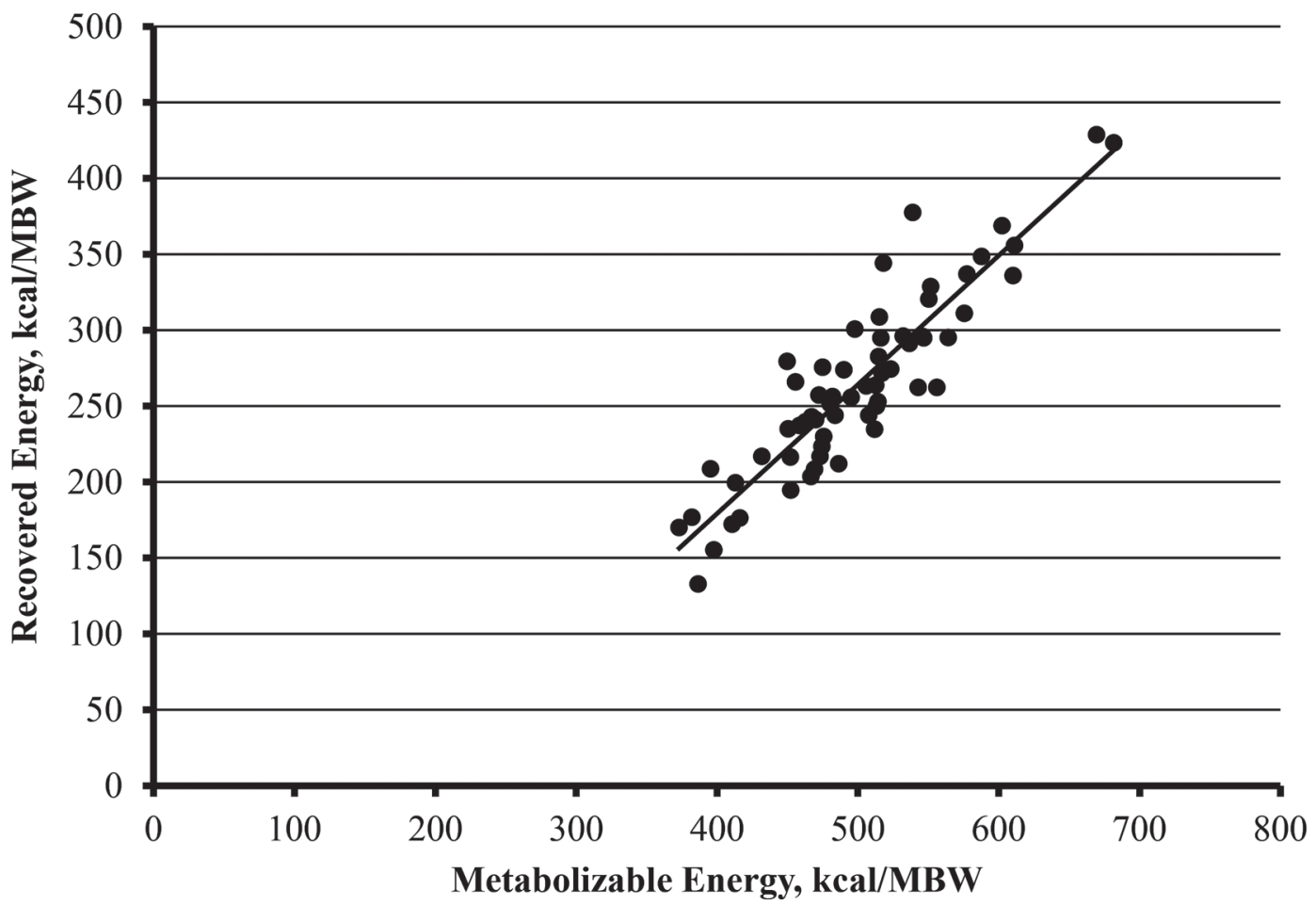

Figure 1. Regression of recovered energy on ME intake in kilocalories per metabolic body weight $\left(\mathrm{kcal} / \mathrm{MBW} ; \mathrm{y}=0.85 \mathrm{x}-160.3 ; \mathrm{R}^{2}=0.82\right.$, root mean squared error $=25.6$ ). Recovered energy $=0$ at $189 \mathrm{kcal}$ of ME/MBW, and efficiency of converting ME to lactation energy is $85 \%$.

often been observed to increase by 5 to $12 \%$ when DDGS were included in the diet (Benchaar et al., 2013; Castillo-Lopez et al., 2014). Compared with CON, DMI was not affected $(P=0.13)$ with the inclusion of DDGS nor by the addition to either oil or CaS to diets containing DDGS and averaged $19.7 \pm 0.37 \mathrm{~kg} / \mathrm{d}$ across treatments (Table 4). It is likely that positive responses previously observed are at least in part related to those ingredients removed when DDGS are included in the diet. For example, Castillo-Lopez et al. (2014) observed that when DDGS replace a portion of forage feed intake may increase and this may in part been due to lesser effects of finer particles in DDGS to affect gut fill. In the current study, we suggest DMI was not affected because forages were held constant across treatments and particle size measures were similar among diets.

Similar to the increased DMI observed with feeding DDGS, milk yield has also been reported to increase (Benchaar et al., 2013). However, a concern with feeding DDGS is the increased fat concentration in the diet and the potential effects on milk production and milk fat yield (Ramirez-Ramirez et al., 2015). Abdelqader et al. (2009) fed diets containing either 30\% DDGS or $2.5 \% \mathrm{CO}$ and observed a lower milk fat percentage compared with a control diet. However, Janicek et al. (2008) fed up to 30\% DDGS without any negative effects on milk yield or milk composition. In the current study, compared with CON, milk yield was different $(P$ $\leq 0.02$; Table 4) and was greater in all 3 treatments containing DDGS. Compared with CON, ECM was greater $(P \leq 0.02)$ with the inclusion of DG and $\mathrm{CO}$ treatments (30.1 vs. 31.4 and $31.7 \pm 0.52 \mathrm{~kg} / \mathrm{d}$ for CON vs. DG and $\mathrm{CO}$, respectively). Treatments containing DDGS did not differ in ECM $(P \geq 0.20)$ averaging $31.4 \pm 0.52 \mathrm{~kg} / \mathrm{d}$. Milk fat percentage and yield did not differ $(P=0.32$ and 0.22$)$ among treatments with a mean of $4.61 \pm 0.10 \%$ and $1.23 \pm 0.03 \mathrm{~kg} / \mathrm{d}$, respectively. Previous research conducted at the University of Nebraska has observed a tendency for greater milk production with inclusion of DDGS (Foth et al., 2015). Schingoethe et al. (2009) also observed greater milk production when using wet or dry distillers grains. Previous research from our laboratory also indicated that the inclusion of $\mathrm{CO}$ can induce milk fat depression (Ramirez-Ramirez et al., 2015). Interestingly, the current study did not observe a depression in milk fat, which may be due to low concentrations of crude fat for all treatments. Ramirez-Ramirez et al. (2015) induced milk fat depression with increasing total dietary fat from 5.0 to $6.5 \%$ and in the current study, the CO diet did not reach $5 \%$ dietary fat. Milk protein percent and yield $(P=0.10$ and 0.12$)$ did not differ among diets averaging $3.23 \pm 0.04 \%$ and $0.87 \pm 0.02 \mathrm{~kg} / \mathrm{d}$. Milk urea nitrogen was greater $(P<0.01)$ for the CON 
JUDY ET AL.

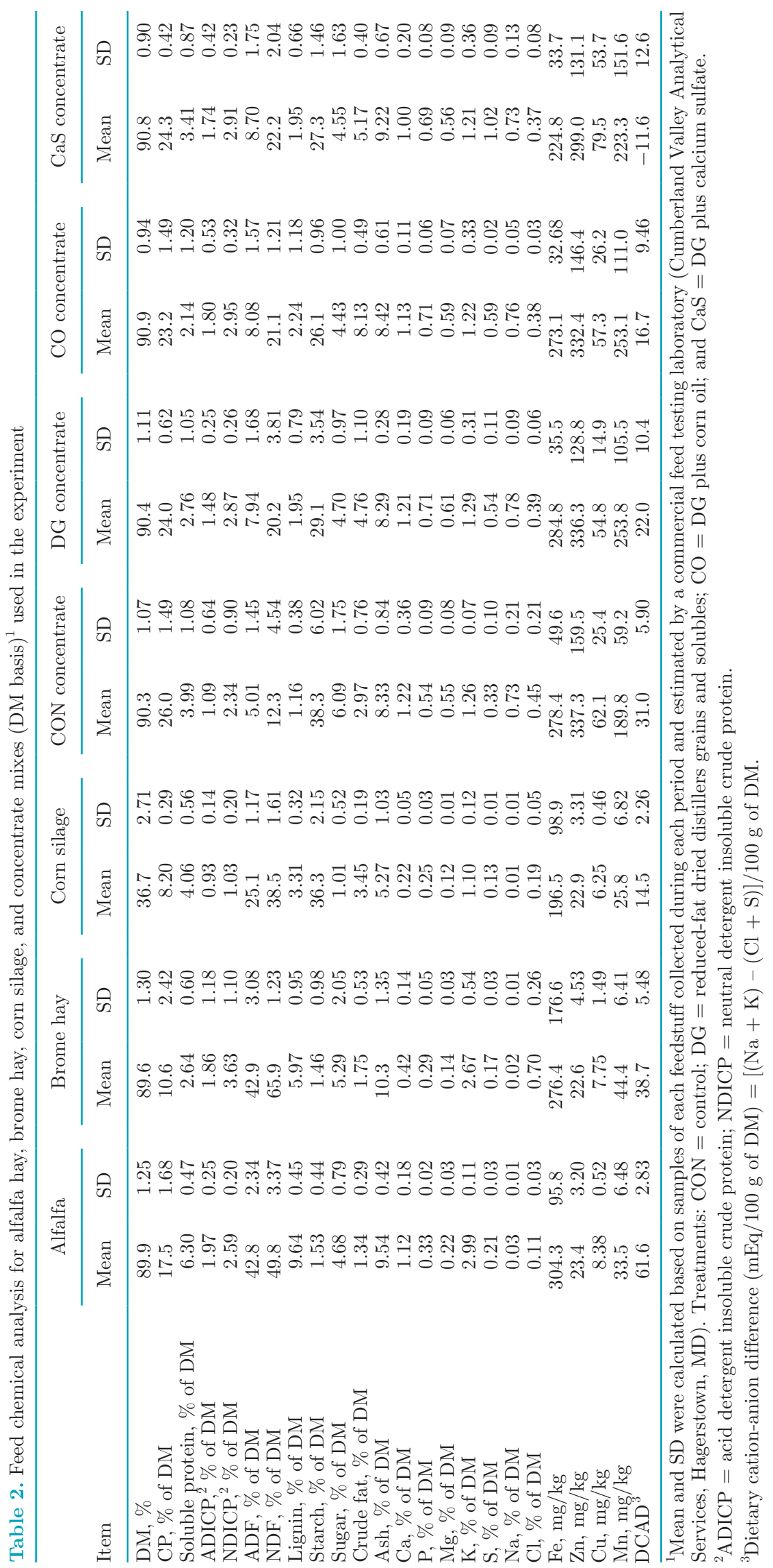


Table 3. Particle distribution (\%) of dietary treatments formulated to reduce methane (as-fed basis) ${ }^{1}$

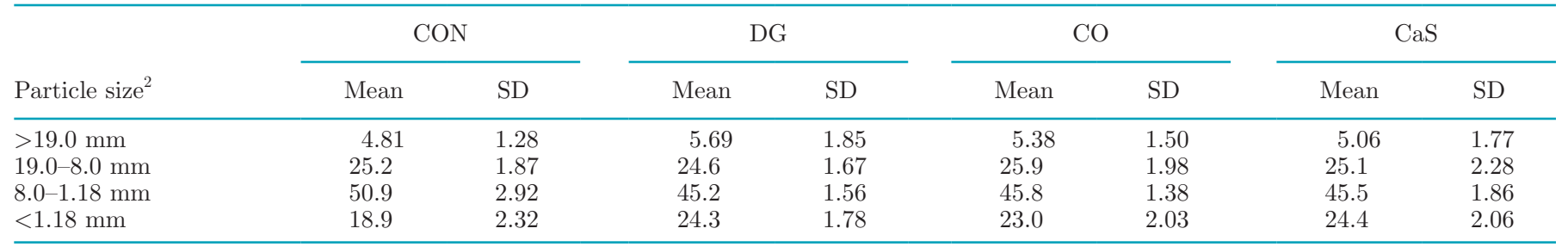

${ }^{1}$ Treatments: $\mathrm{CON}=$ control; $\mathrm{DG}=$ reduced-fat dried distillers grains and solubles; $\mathrm{CO}=\mathrm{DG}$ plus corn oil; and CaS = DG plus calcium sulfate. ${ }^{2}$ Determined using the Penn State Particle Separator on wet basis (Heinrichs and Kononoff, 2002).

compared with all 3 treatments containing DDGS (17.3 vs. $14.9 \pm 0.41 \mathrm{mg} / \mathrm{dL}$ for CON vs. DDGS, respectively). Increased MUN have been observed with excess protein in the diet (Roseler et al., 1993). In the current study, greater MUN observed in animals consuming the CON treatment was likely a result of increased dietary protein. Soybean meal was removed with the inclusion of DDGS, which resulted in lower CP concentrations. Free water intake was measured using line meters and did not differ $(P=0.32)$ by treatment with an overall mean of $84.8 \pm 4.14 \mathrm{~L} / \mathrm{d}$ (Table 4 ; see Table 5 for data on water quality).

\section{Gas Consumption and Production}

While attempting to reduce $\mathrm{CH}_{4}$ production, there is potential to alter the metabolism of the animal and thus affect $\mathrm{O}_{2}$ and $\mathrm{CO}_{2}$ production. However, recent work attempting to reduce $\mathrm{CH}_{4}$ has not resulted in any effects on $\mathrm{O}_{2}$ consumption or $\mathrm{CO}_{2}$ production in lac- tating Holstein cattle (Olijhoek et al., 2016). Likewise, in the current study, $\mathrm{O}_{2}$ consumption did not differ $(P=0.44)$ averaging 4,972.1 $\pm 119.8 \mathrm{~L} / \mathrm{d}$ (Table 6). Carbon dioxide production did not differ $(P=0.33)$ by treatment with an overall mean of $5,277.3 \pm 135.1$ $\mathrm{L} / \mathrm{d}$ observed. Treatment tended $(P=0.07)$ to reduce total $\mathrm{CH}_{4}$ production. The inclusion of DDGS has been previously observed to reduced $\mathrm{CH}_{4}$ production in lactating dairy cows (Benchaar et al., 2013; Foth et al., 2015). However, in the current study, compared with CON not containing DDGS, total $\mathrm{CH}_{4}$ production was only reduced in the diet containing CaS and DDGS. As mentioned earlier, we have previously observed a $7 \%$ reduction in $\mathrm{CH}_{4}$ with feeding reduced-fat DDGS (Foth et al., 2015). Similarly, DDGS have reduced $\mathrm{CH}_{4}$ in both beef and dairy cattle (McGinn et al., 2009; Benchaar et al., 2013). Previous research indicates that reduced $\mathrm{CH}_{4}$ production with added DDGS was the result of the effect of fat on fermentation by suppressing methanogens and perhaps to a lesser extent

Table 4. Dry matter intake, milk production and composition, BW, BCS, and water intake of treatments formulated to reduce methane in lactating dairy cattle

\begin{tabular}{|c|c|c|c|c|c|c|}
\hline \multirow[b]{2}{*}{ Item } & \multicolumn{4}{|c|}{ Treatment $^{1}$} & \multirow[b]{2}{*}{$\mathrm{SEM}^{2}$} & \multirow[b]{2}{*}{$P$-value } \\
\hline & $\mathrm{CON}$ & DG & $\mathrm{CO}$ & $\mathrm{CaS}$ & & \\
\hline DMI, kg/d & 19.1 & 20.1 & 20.0 & 19.6 & 0.37 & 0.13 \\
\hline Milk yield, $\mathrm{kg} / \mathrm{d}$ & $26.3^{\mathrm{b}}$ & $27.5^{\mathrm{a}}$ & $28.3^{\mathrm{a}}$ & $27.6^{\mathrm{a}}$ & 0.67 & $<0.01$ \\
\hline $\mathrm{ECM}^{3}{ }^{3} \mathrm{~kg} / \mathrm{d}$ & $30.1^{\mathrm{b}}$ & $31.4^{\mathrm{a}}$ & $31.7^{\mathrm{a}}$ & $31.0^{\mathrm{ab}}$ & 0.66 & 0.02 \\
\hline Fat, $\%$ & 4.70 & 4.64 & 4.53 & 4.57 & 0.10 & 0.32 \\
\hline Fat yield, $\mathrm{kg} / \mathrm{d}$ & 1.19 & 1.25 & 1.24 & 1.22 & 0.03 & 0.22 \\
\hline Protein, $\%$ & 3.28 & 3.26 & 3.18 & 3.20 & 0.04 & 0.11 \\
\hline Protein yield, kg/d & 0.84 & 0.87 & 0.88 & 0.86 & 0.02 & 0.12 \\
\hline Lactose, \% & 4.90 & 4.91 & 4.92 & 4.92 & 0.02 & 0.77 \\
\hline MUN, mg/dL & $17.3^{\mathrm{a}}$ & $15.0^{\mathrm{bc}}$ & $14.4^{\mathrm{c}}$ & $15.3^{\mathrm{b}}$ & 0.59 & $<0.01$ \\
\hline $\mathrm{SCC}$, cells $/ \mathrm{mL}$ & 98.7 & 111.3 & 136.7 & 133.6 & 39.7 & 0.74 \\
\hline Free water intake, $\mathrm{L} / \mathrm{d}$ & 82.1 & 84.3 & 89.5 & 83.2 & 3.61 & 0.32 \\
\hline $\mathrm{BW}, \mathrm{kg}$ & 508.1 & 513.4 & 513.2 & 510.7 & 11.1 & 0.50 \\
\hline $\mathrm{BCS}^{4}$ & $3.23^{\mathrm{a}}$ & $3.13^{\mathrm{b}}$ & $3.16^{\mathrm{ab}}$ & $3.20^{\mathrm{ab}}$ & 0.06 & 0.06 \\
\hline
\end{tabular}

${ }^{\mathrm{a}-\mathrm{c}}$ Means within rows lacking common superscript differ $(P<0.05)$.

${ }^{1}$ Treatments: $\mathrm{CON}=$ control; $\mathrm{DG}=$ reduced-fat dried distillers grains and solubles; $\mathrm{CO}=\mathrm{DG}$ plus corn oil; and $\mathrm{CaS}=\mathrm{DG}$ plus calcium sulfate.

${ }^{2}$ Lowest standard error of treatment means is listed.

${ }^{3} \mathrm{ECM}=0.327 \times$ milk yield $(\mathrm{kg})+12.95 \times$ fat $(\mathrm{kg})+7.2 \times$ protein $(\mathrm{kg})$ adjusted for $3.5 \%$ fat and $3.2 \%$ total protein (DRMS, 2014).

${ }^{4}$ BCS: 1 to 5 scale according to Wildman et al. (1982). 
Table 5. Water quality constituent analysis of on-site water used in the experiment $(\mathrm{n}=4)$

\begin{tabular}{lcc}
\hline Item & Mean & $\mathrm{SD}$ \\
\hline Constituent, mg/kg & & \\
Total dissolved solids & 373.1 & 14.9 \\
$\mathrm{Ca}$ & 59.4 & 4.44 \\
$\mathrm{Cl}$ & 23.3 & 1.98 \\
$\mathrm{Fe}$ & 0.01 & 0.02 \\
$\mathrm{Fl}$ & 0.89 & 0.06 \\
$\mathrm{Mg}$ & 14.0 & 1.39 \\
$\mathrm{NO}_{3}$-N & 0.64 & 0.14 \\
$\mathrm{Na}_{\mathrm{SO}}$ & 36.4 & 5.17 \\
$\mathrm{Conductivity,} \mathrm{mS} / \mathrm{cm}$ & 92.0 & 10.00 \\
$\mathrm{Hardness}$, & 0.57 & 0.02 \\
$\mathrm{pH}$ & 12.0 & 0.92 \\
\hline
\end{tabular}

potential biohydrogenation of UFA (Benchaar et al., 2013). Compared with CON not containing DDGS, the addition of CaS to diets containing DDGS tended to reduce $\mathrm{CH}_{4}$ production. Similarly, van Zijderveld et al. (2010) observed a reduction of $16 \%$ with added sulfur in sheep. However, using diallyl disulfide in lactating dairy cows, van Zijderveld et al. (2011) did not observe a reduction in $\mathrm{CH}_{4}$ production, which may be a result of too low of sulfur inclusion. The dairy NRC (2001) set the maximum tolerable concentration of dietary sulfur at $0.4 \%$. In the current study, dietary sulfur exceeded this recommendation without negatively affecting DMI, milk production, or overall health of the cows. This may indicate that the source of sulfur added to the diet may affect methanogens differently and ultimately $\mathrm{CH}_{4}$ production. However, caution should still be exercised with sulfur to prevent possible metabolic disorders.

One alternative method to determine the effects of $\mathrm{CH}_{4}$ mitigation strategies is to consider the effects on efficiency. Increasing overall efficiency may be the most effective way to reduce total $\mathrm{CH}_{4}$. Determining $\mathrm{CH}_{4}$ per unit of milk produced, and $\mathrm{CH}_{4}$ per unit of DMI are informative ways to assess the effectiveness of a mitigation strategy and in the current study, both of these measures were affected by $\operatorname{diet}(P<0.01$ and 0.02$)$. Previous research has indicated that $\mathrm{CH}_{4}$ production can be reduced $10 \%$ per unit of milk production when feeding DDGS (Foth et al., 2015). In the current study, $\mathrm{CH}_{4}$ per unit of ECM and DMI did not differ between CON and DG treatments; however, a reduction was observed when $\mathrm{CO}$ and $\mathrm{CaS}$ were added to diets containing DDGS.

Heat production is a loss of energy that in indirect calorimetry is calculated from $\mathrm{O}_{2}$ consumption and $\mathrm{CO}_{2}$ production from respired air from the animal (Blaxter, 1962). In the current study, HP did not differ $(P=0.43)$ by treatment with an overall mean of $25.1 \pm$ $0.62 \mathrm{Mcal} / \mathrm{d}$. Similarly, HP per unit of metabolic body weight $(\mathrm{MBW})$ did not differ $(P=0.54)$ by treatment with an overall mean of $251.9 \pm 5.64 \mathrm{kcal} / \mathrm{BW}^{0.75}$ and is similar to the observations of van Knegsel et al. (2007). The respiratory quotient ( $\mathbf{R Q})$ is the ratio of $\mathrm{CO}_{2}$ produced to $\mathrm{O}_{2}$ consumed. In the current study, RQ tended $(P=0.06)$ to be affected by treatment. The RQ was reduced $(P=0.05)$ with the inclusion of $\mathrm{CO}(1.07$ vs. $1.05 \pm 0.01$ for $\mathrm{CON}$ vs. CO, respectively), yet this reduction is small and is likely not biologically relevant.

\section{Nutrient Digestibility}

The digestibility of nutrients has been reported to decrease with increasing concentrations of DDGS (Benchaar et al., 2013). Previous research has indicated decreased DM digestibility with inclusion of DDGS (Foth et al., 2015). Similar reductions in fiber digest-

Table 6. Methane production, methane efficiencies, and heat production for treatments formulated to reduce methane in lactating dairy cattle

\begin{tabular}{|c|c|c|c|c|c|c|}
\hline \multirow[b]{2}{*}{ Item } & \multicolumn{4}{|c|}{ Treatment $^{1}$} & \multirow[b]{2}{*}{$\mathrm{SEM}^{2}$} & \multirow[b]{2}{*}{$P$-value } \\
\hline & $\mathrm{CON}$ & $\mathrm{DG}$ & $\mathrm{CO}$ & $\mathrm{CaS}$ & & \\
\hline $\mathrm{O}_{2}$ consumption, $\mathrm{L} / \mathrm{d}$ & $4,978.2$ & $5,107.1$ & $4,862.4$ & $4,940.7$ & 119.8 & 0.44 \\
\hline $\mathrm{CO}_{2}$ production, L/d & $5,331.4$ & $5,427.4$ & $5,105.2$ & $5,245.3$ & 135.1 & 0.33 \\
\hline $\mathrm{CH}_{4}$ production, $\mathrm{L} / \mathrm{d}$ & $421.6^{\mathrm{a}}$ & $429.5^{\mathrm{a}}$ & $394.7^{\mathrm{ab}}$ & $381.4^{\mathrm{b}}$ & 14.4 & 0.07 \\
\hline $\mathrm{CH}_{4} /$ milk yield, $\mathrm{L} / \mathrm{kg}$ per day & $16.7^{\mathrm{a}}$ & $16.2^{\mathrm{a}}$ & $14.4^{\mathrm{b}}$ & $14.3^{\mathrm{b}}$ & 0.60 & $<0.01$ \\
\hline $\mathrm{CH}_{4} / \mathrm{ECM}, \mathrm{L} / \mathrm{kg}$ per day & $14.2^{\mathrm{a}}$ & $13.8^{\mathrm{ab}}$ & $12.5^{\mathrm{bc}}$ & $12.4^{\mathrm{c}}$ & 0.50 & 0.02 \\
\hline $\mathrm{RQ},{ }^{3} \mathrm{~L} / \mathrm{L}$ & $1.07^{\mathrm{a}}$ & $1.06^{\mathrm{ab}}$ & $1.05^{\mathrm{b}}$ & $1.06^{\mathrm{ab}}$ & 0.01 & 0.06 \\
\hline $\mathrm{CH}_{4} / \mathrm{DMI}, \mathrm{L} / \mathrm{kg}$ per day & $22.3^{\mathrm{a}}$ & $21.4^{\mathrm{ab}}$ & $19.9^{\mathrm{b}}$ & $19.6^{\mathrm{b}}$ & 0.75 & 0.05 \\
\hline $\mathrm{HP},{ }^{4} \mathrm{Mcal} / \mathrm{d}$ & 25.1 & 25.8 & 24.4 & 24.9 & 0.62 & 0.43 \\
\hline $\mathrm{HP}, \mathrm{kcal} / \mathrm{BW}^{0.75}$ & 253.7 & 256.9 & 246.5 & 250.5 & 5.64 & 0.54 \\
\hline
\end{tabular}

\footnotetext{
${ }^{\mathrm{a}-\mathrm{c}}$ Means within rows lacking common superscript differ $(P<0.05)$.

${ }^{1}$ Treatments: $\mathrm{CON}=$ control; $\mathrm{DG}=$ reduced-fat dried distillers grains and solubles; $\mathrm{CO}=\mathrm{DG}$ plus corn oil; and CaS $=\mathrm{DG}$ plus calcium sulfate. ${ }^{2}$ Lowest standard error of treatment means is listed.

${ }^{3} \mathrm{RQ}=$ respiratory quotient $\left(\mathrm{CO}_{2}\right.$ production $/ \mathrm{O}_{2}$ consumption $)$.

${ }^{4} \mathrm{HP}=$ heat production, calculated with Brouwer's (1965) equation from $\mathrm{O}_{2}$ consumption $(\mathrm{L}), \mathrm{CO}_{2}$ production $(\mathrm{L})$, methane production (L), and urine- $\mathrm{N}(\mathrm{g})\left(\mathrm{HP}=3.866 \times \mathrm{O}_{2}+1.200 \times \mathrm{CO}_{2}-0.518 \times \mathrm{CH}_{4}-1.431 \times \mathrm{N}\right)$.
} 
ibility have been observed when supplementing fat (Huhtanen et al., 2009). In the current study, compared with CON, DM digestibility was decreased $(P<0.01)$ for all 3 treatments containing DDGS (68.5 vs. $66.7 \pm$ $0.47 \%$ for CON vs. DDGS, respectively; Table 7 ). On an OM basis, compared with CON, digestibility was also decreased $(P<0.01)$ for all 3 treatments containing DDGS (69.8 vs. $68.7 \pm 0.47 \%$ for CON vs. DDGS, respectively). Compared with DG, OM digestibility decreased with the inclusion of CaS (68.4 vs. $67.2 \pm 0.47 \%$ for DG vs. CaS, respectively). Although digestibility of CP was affected by treatment $(P=0.02)$, it did not differ between CON and DG treatments with a mean of $72.3 \pm 0.50 \%$, which is similar to observations by Foth et al. (2015). Compared with CON, CP digestibility decreased $(P \leq 0.01)$ with the inclusion of $\mathrm{CO}$ and $\mathrm{CaS}$ to diets containing DDGS (72.8 vs. 71.0 and $71.0 \pm 0.50 \%$ for $\mathrm{CON}$ vs. $\mathrm{CO}$ and $\mathrm{CaS}$, respectively). Some suggest that the addition of sulfate decreases digestibility of NDF; however, van Zijderveld et al. (2011) observed no difference on NDF digestibility while supplementing diallyl disulfide to lactating dairy cows. Likewise, in the current study, NDF digestibility did not differ $(P$ $=0.25)$ by treatment with a mean of $53.8 \pm 0.72 \%$. Starch digestibility did not differ $(P=0.16)$ among treatments with an overall mean of $92.7 \pm 0.51 \%$.

\section{Energy Partitioning}

Total Energy Intake. Predicted energy values tend to be low when formulating rations containing DDGS; however, observed energy estimates have been observed to be 7 to $11 \%$ greater in DDGS diets (Birkelo et al., 2004). Compared with CON, GE intake was affected by treatment $(P<0.01$; Table 8$)$ and compared with CON was higher in all 3 treatments containing DDGS. Compared with CON, intake of digestible energy (DE) was affected by treatment $(P<0.01)$ and was lowest in the diet containing DDGS and CaS. Metabolizable energy intake was affected by treatment $(P<0.01)$ and was highest in all 3 treatments containing DDGS. The $\mathrm{ME}$ as a percentage of GE did not differ $(P=0.19)$ by treatment with a mean of $60.3 \pm 0.50 \%$. Compared with CON, intake net balance (milk plus TE) of energy was greater in DG and CO with DDGS (25.9 vs. 29.6 and $31.1 \pm 1.08 \mathrm{Mcal} / \mathrm{d}$ for CON vs. DG and CO, respectively). These findings support our hypothesis that energy balance would increase with the addition of $\mathrm{CO}$ but the addition of CaS did not increase net energy balance. Inclusion of DDGS increased ME and net energy balance because the supply of energy from this feed was greater than the sum total of the ingredients replaced (Schingoethe et al., 2009; Foth et al., 2015).

Losses of Energy. Dairy cattle lose energy from the feces, urine, $\mathrm{CH}_{4}$, and heat (Coppock, 1985). Fecal energy loss accounts for approximately one-third of energy lost for cattle, whereas urine and methane account for approximately 3 and $5 \%$, respectively (Coppock, 1985). In the current study, fecal energy lost as a percentage of GE tended $(P=0.08)$ to be affected by treatment, and inclusion of $\mathrm{CO}$ in the present study increased fecal energy loss as a percent of GE compared with CON (30.7 vs. $33.7 \pm 1.19 \%$ for $\mathrm{CON}$ vs. CO, respectively). The increased energy in the feces may be the result of decreased digestibility of the fat; however, crude fat digestibility was not measured in this study. Heat energy as a percentage of GE was reduced $(P<$ 0.01 ) for all 3 treatments containing DDGS compared with CON (30.0 vs. $27.8 \pm 0.85 \%$ ). Heat production as a percentage of GE may have been reduced in diets containing DDGS due to the decreased digestibility and thus decreased rumen fermentation. Methane energy as a percentage of GE was affected by treatment $(P$ $=0.01$ ) and compared with CON, was lower with the inclusion of $\mathrm{CO}$ and $\mathrm{CaS}$ to diets containing DDGS (4.78 vs. 4.11 and $4.11 \pm 0.16 \%$ for CON vs. CO and CaS, respectively). Similarly, Hales et al. (2017) observed that when $\mathrm{CO}$ is included at $2 \%$ of the diet DM,

Table 7. Apparent nutrient digestibility of treatments formulated to reduce methane production in lactating dairy cattle

\begin{tabular}{lcccccc}
\hline & \multicolumn{5}{c}{ Treatment $^{1}$} \\
Component & CON & DG & CO & CaS & \multirow{2}{*}{ SEM $^{2}$} & $P$-value \\
\hline DM, \% & $68.5^{\mathrm{a}}$ & $67.2^{\mathrm{b}}$ & $66.7^{\mathrm{b}}$ & $66.3^{\mathrm{b}}$ & 0.47 & $<0.01$ \\
OM, \% & $69.8^{\mathrm{a}}$ & $68.4^{\mathrm{b}}$ & $67.9^{\mathrm{bc}}$ & $67.2^{\mathrm{c}}$ & 0.47 & $<0.01$ \\
CP, \% & $72.8^{\mathrm{a}}$ & $71.8^{\mathrm{ab}}$ & $71.0^{\mathrm{b}}$ & $71.0^{\mathrm{b}}$ & 0.50 & 0.02 \\
NDF, \% & 52.8 & 54.3 & 54.3 & 53.7 & 0.72 & 0.25 \\
Starch, \% & 93.4 & 92.9 & 92.2 & 92.1 & 0.51 & 0.16 \\
Ash, \% & 45.1 & 44.9 & 45.7 & 42.8 & 1.20 & 0.22 \\
\hline
\end{tabular}

${ }^{a-c}$ Means within a row with different superscripts differ $(P<0.05)$.

${ }^{1}$ Treatments: CON $=$ control; DG $=$ reduced-fat dried distillers grains and solubles; $\mathrm{CO}=\mathrm{DG}$ plus corn oil; and $\mathrm{CaS}=\mathrm{DG}$ plus calcium sulfate.

${ }^{2}$ Lowest SE of treatment means is listed. 
$\mathrm{CH}_{4}$ energy as a percentage of GE intake was reduced by $13 \%$ and Beauchemin et al. (2007) observed a $20 \%$ decrease with sunflower oil. Dietary fat is believed to reduce $\mathrm{CH}_{4}$ by 3 different mechanisms, increasing the propionate concentration with altering of the microbial community, utilizing hydrogens during biohydrogenation, and in some cases may result in a reduction in rumen NDF digestion (Nagaraja et al., 1997).

Energy Gains. Energy gains in the animal can be characterized as energy recovered by the animal, which includes energy in tissue, milk, and conceptus if the animal is pregnant (Ferrell and Oltjen, 2008). In the current study, retained energy (RE) is the sum of tissue and milk energy and was affected by treatment $(P$ $<0.01)$, but milk energy was not affected $(P=0.20)$. Compared with CON, DG increased RE (25.9 vs. 29.6 $\pm 1.08 \mathrm{Mcal} / \mathrm{d}$ ). Compared with CON, inclusion of $\mathrm{CO}$ to diets containing DDGS increased RE (25.9 vs. 31.2 $\pm 1.08 \mathrm{Mcal} / \mathrm{d}$ ). Retained energy did not differ between $\mathrm{CaS}$ and either CON of DG. Compared with CON, TE was also affected by treatment $(P=0.04)$ and was greater in DG (3.19 vs. $6.08 \pm 0.99 \mathrm{Mcal} / \mathrm{d})$. Variable results have been observed on the effects of including DDGS on TE. Foth et al. (2015) observed increased TE with the inclusion of DDGS, whereas Birkelo et al. (2004) observed a decrease in TE with the inclusion of wet DGS. The discrepancy could be caused by the decrease in DMI for wet DGS compared with DDGS, which was used in both the study by Foth et al. (2015) and the current study. Compared with CON, TE was greater with the inclusion of $\mathrm{CO}$ in diets containing DDGS (3.19 vs. $7.04 \pm 0.99 \mathrm{Mcal} / \mathrm{d})$, whereas no difference was observed between the CON and when CaS was added to a diet containing DDGS. Treatments containing DDGS did not differ in TE with a mean of $5.89 \pm 0.99 \mathrm{Mcal} / \mathrm{d}$.

Energy Intake Per Unit of DM. A 4 to $6 \%$ increase in GE content of TMR has been observed with the inclusion of DDGS (Birkelo et al., 2004; Foth et al., 2015). Compared with CON, GE content per $\mathrm{kg}$ of DM was greater $(P<0.01)$ for DG $(4.40$ vs. $4.53 \pm$ 0.01 for CON vs. DG, respectively), which may be expected due to the higher lipid content from the DDGS. This resulted in a 3\% increase in GE for the DG diet. Compared with CON and DG, GE content per $\mathrm{kg}$ of $\mathrm{DM}$ was greater in $\mathrm{CO}$ (4.40 and 4.53 vs. $4.58 \pm 0.01$ $\mathrm{Mcal} / \mathrm{kg}$ of DM for CON and DG vs. CO, respectively). Digestible energy has also been reported to increase by $5 \%$ with DDGS (Birkelo et al., 2004). However, in the current study, DE was similar between the CON and DG treatments. Compared with CON, DE per kg of $\mathrm{DM}$ was greater with the inclusion of $\mathrm{CO}$ to diets

Table 8. Partitioning of energy for dietary treatments formulated to reduce methane in lactating dairy cattle

\begin{tabular}{|c|c|c|c|c|c|c|}
\hline Item $^{1}$ & \multicolumn{4}{|c|}{ Treatment $^{2}$} & $\mathrm{SEM}^{3}$ & $P$-value \\
\hline GE intake, Mcal/d & $84.0^{\mathrm{b}}$ & $91.2^{\mathrm{a}}$ & $91.6^{\mathrm{a}}$ & $88.7^{\mathrm{a}}$ & 1.67 & $<0.01$ \\
\hline ME, Mcal/d & $50.5^{\mathrm{b}}$ & $54.8^{\mathrm{a}}$ & $55.0^{\mathrm{a}}$ & $52.3^{\mathrm{a}}$ & 1.08 & $<0.01$ \\
\hline Net balance, Mcal/d & $25.9^{\mathrm{c}}$ & $29.6^{\mathrm{ab}}$ & $31.2^{\mathrm{a}}$ & $27.9^{\mathrm{bc}}$ & 1.08 & $<0.01$ \\
\hline \multicolumn{7}{|l|}{ Component, Mcal/d } \\
\hline Heat & 25.1 & 25.8 & 24.4 & 24.9 & 0.62 & 0.43 \\
\hline $\mathrm{RE}$ & $25.9^{\mathrm{c}}$ & $29.6^{\mathrm{ab}}$ & $31.2^{\mathrm{a}}$ & $27.9^{\mathrm{bc}}$ & 1.07 & $<0.01$ \\
\hline Milk & 22.7 & 23.5 & 24.1 & 23.4 & 0.58 & 0.20 \\
\hline $\mathrm{TE}$ & $3.16^{\mathrm{b}}$ & $6.08^{\mathrm{a}}$ & $7.04^{\mathrm{a}}$ & $4.54^{\mathrm{ab}}$ & 0.99 & 0.04 \\
\hline $\mathrm{DE}, \%$ of $\mathrm{GE}$ & $68.7^{\mathrm{a}}$ & $68.0^{\mathrm{a}}$ & $67.6^{\mathrm{ab}}$ & $66.5^{\mathrm{b}}$ & 0.52 & $<0.01$ \\
\hline ME, $\%$ of GE & 60.7 & 60.6 & 60.5 & 59.5 & 0.61 & 0.19 \\
\hline $\mathrm{TE}, \%$ of $\mathrm{GE}$ & $3.58^{\mathrm{b}}$ & $6.48^{\mathrm{ab}}$ & $7.36^{\mathrm{b}}$ & $4.72^{\mathrm{ab}}$ & 1.06 & 0.07 \\
\hline GE, Mcal/kg of DM & $4.40^{\mathrm{c}}$ & $4.53^{\mathrm{b}}$ & $4.59^{\mathrm{a}}$ & $4.52^{\mathrm{b}}$ & 0.01 & $<0.01$ \\
\hline $\mathrm{DE}, \mathrm{Mcal} / \mathrm{kg}$ of DM & $3.03^{\mathrm{bc}}$ & $3.09^{\mathrm{ab}}$ & $3.10^{\mathrm{a}}$ & $3.01^{\mathrm{c}}$ & 0.03 & 0.01 \\
\hline $\mathrm{ME}, \mathrm{Mcal} / \mathrm{kg}$ of DM & $2.67^{\mathrm{b}}$ & $2.75^{\mathrm{a}}$ & $2.78^{\mathrm{a}}$ & $2.69^{\mathrm{b}}$ & 0.03 & $<0.01$ \\
\hline Net balance, Mcal/kg of DM & $1.35^{\mathrm{c}}$ & $1.47^{\mathrm{ab}}$ & $1.55^{\mathrm{a}}$ & $1.41^{\mathrm{bc}}$ & 0.06 & $<0.01$ \\
\hline
\end{tabular}

${ }^{a-c}$ Means within a row with different superscripts differ $(P<0.05)$.

${ }^{1} \mathrm{GE}=$ gross energy; $\mathrm{DE}=$ digestible energy; net balance = milk plus tissue energy; $\mathrm{RE}=$ retained energy; TE $=$ tissue energy.

${ }^{2}$ Treatments: $\mathrm{CON}=$ control; $\mathrm{DG}=$ reduced-fat dried distillers grains and solubles; $\mathrm{CO}=\mathrm{DG}$ plus corn oil; and CaS = DG plus calcium sulfate.

${ }^{3}$ Lowest SE of treatment means is listed. 
containing DDGS (3.03 vs. $3.10 \pm 0.03 \mathrm{Mcal} / \mathrm{kg}$ of DM for CON vs. CO, respectively). Digestible energy for DG was greater than CaS (3.09 vs. $3.01 \pm 0.03 \mathrm{Mcal} / \mathrm{kg}$ of DM for CaS vs. DG). Birkelo et al. (2004) observed a $5 \%$ increase in $\mathrm{ME}$ (Mcal $/ \mathrm{kg}$ of $\mathrm{DM}$ ) with the inclusion of DDGS. In the current study, DG increased ME per $\mathrm{kg}$ of DM by $3 \%$ compared with CON (2.67 vs. $2.75 \pm$ $0.03 \mathrm{Mcal} / \mathrm{kg}$ of DM for CON vs. DG, respectively). Compared with CON, ME per $\mathrm{kg}$ of DM increased when $\mathrm{CO}$ was added to a diet containing DDGS (2.67 vs. 2.78 $\pm 0.03 \mathrm{Mcal} / \mathrm{kg}$ of DM for CON vs. CO, respectively). Net balance (milk plus tissue) of energy increased by 3 to $7 \%$ in previous work done with DDGS (Birkelo et al., 2004; Foth et al., 2015). In the current study, in the case of DG we observed a $9 \%$ increase in net balance (tissue plus milk) of energy per $\mathrm{kg}$ of $\mathrm{DM}$ and a $15 \%$ increase $(P=0.001)$ with the inclusion of $\mathrm{CO}$ to diets containing DDGS (1.35 vs. 1.47 and $1.55 \pm 0.04 \mathrm{Mcal} /$ $\mathrm{kg}$ of DM for CON vs. DG and CO, respectively). More energy was available for lactation from the DG and CO treatments with a similar net energy balance compared with Foth et al. (2015). Overall, the inclusion of DDGS, and $\mathrm{CO}$ increased energy available for lactation and tissue.

Maintenance Energy and Efficiency of Energy Use for Lactation. Estimated maintenance energy requirement is illustrated in Figure 1 and was determined through regression of $\mathrm{ME}$ intake and $\mathrm{RE}$ and then solving for ME intake when RE equals zero (Foth et al., 2015). Estimated maintenance requirement was calculated to be $189 \mathrm{kcal} / \mathrm{kg}$ of MBW with efficiency of ME use for lactation $\left(\boldsymbol{k}_{1}\right)$ of 0.85 . In the current study, estimated maintenance requirements and efficiencies were greater than previous estimates, which averaged near $143 \pm 26 \mathrm{kcal} / \mathrm{MBW}$ for maintenance and 0.64 for $k_{1}$ (Birkelo et al., 2004; Moe and Tyrrell, 1971; Vermorel et al., 1982; Xue et al., 2011; Foth et al., 2015). However, Yan et al. (1997) reported maintenance requirements between 146 to $179 \mathrm{kcal} / \mathrm{MBW}$ and $k_{1}$ between 0.61 and 0.68 in lactating dairy cows indicating a large range of variation. Grainger et al., (1985) observed maintenance energy requirements of $184 \mathrm{kcal} / \mathrm{MBW}$, which is similar to the current study. Coppock et al. (1964) observed efficiencies of converting ME to milk between 67 and $107 \%$ with an overall mean around $75 \%$. With increased forage in the diet, it is possible that the maintenance requirement increased. Yan et al. (1997) and Dong et al. (2015) observed increased maintenance requirements with increasing forage percentage in the diet, which was suggested to be caused by increased size of the gastrointestinal tract. In a recent meta-analysis of energy balance data, Moraes et al. (2015) reported an increase in maintenance requirement, which may be correlated with higher genetic merit of cattle. Overall, the maintenance requirements observed in the current study are within the range reported in the literature.

\section{Nitrogen Balance}

Nitrogen balance is the $\mathrm{N}$ remaining after subtracting the $\mathrm{N}$ lost in the feces, urine, and milk from total $\mathrm{N}$ intake. Excretion of $\mathrm{N}$ is affected by total $\mathrm{N}$ intake (Weiss et al., 2009), which has led to highly variable observations in $\mathrm{N}$ balance, particularly when DDGS diets increase intake. Hales et al. (2017) observed a linear increase in urinary $\mathrm{N}$ with increasing concentrations of dietary $\mathrm{CO}$, whereas fecal $\mathrm{N}$ decreased linearly with the inclusion of CO. In contrast, Benchaar et al. (2013) observed a linear increase in $\mathrm{N}$ balance with linear increases in $\mathrm{N}$ intake. This led to decreased $\mathrm{N}$ output in the feces, urine, and milk with increased $\mathrm{N}$ retention in the tissue. In the current study, $\mathrm{N}$ intakes were not different $(P=0.77)$ among treatments $(365.2$ $\pm 8.52 \mathrm{~g} / \mathrm{d}$ ) (Table 9). Similarly, total N excretion (fecal plus urinary nitrogen $)$ did not differ $(P=0.29)$ by treatment, with a mean of $365.2 \pm 8.52 \mathrm{~g} / \mathrm{d}$, which is likely related to similar $\mathrm{N}$ intakes. Nitrogen balance (intake nitrogen minus urinary, fecal, and milk N) did not differ $(P=0.12)$ among the CON, DG, and CaS treatments with a mean of $82.7 \pm 10.7 \mathrm{~g} / \mathrm{d}$.

\section{CONCLUSIONS}

Compared with CON, the inclusion of CaS to diets containing DDGS decreased total methane production. In addition, compared with $\mathrm{CON}$, the inclusion of $\mathrm{CO}$ or CaS to diets containing DDGS decreased methane production per unit of feed consumed. The inclusion of DDGS to the diet increased milk yield. Compared with CON net balance (milk plus tissue) of energy concentration in diets containing DDGS alone or along with oil was higher. Nitrogen intake and balance were not affected by the inclusion of DDGS of with oil and CaS. Overall, the dietary strategy to reduce methane production through the addition of oil to diets containing DDGS may also improve energy balance in lactating dairy cattle, whereas the addition of CaS to diets containing DDGS only reduced methane production.

\section{ACKNOWLEDGMENTS}

The authors acknowledge the Nebraska Environmental Trust (Lincoln, NE) for partial financial support of this project. The authors also express thanks to the staff and student of the University of Nebraska-Lincoln Dairy Metabolism facility for their efforts in management and care of experimental animals. Mention of trade names or commercial products in this article is 
Table 9. Partitioning of nitrogen for dietary treatments formulated to reduce methane in lactating dairy cattle

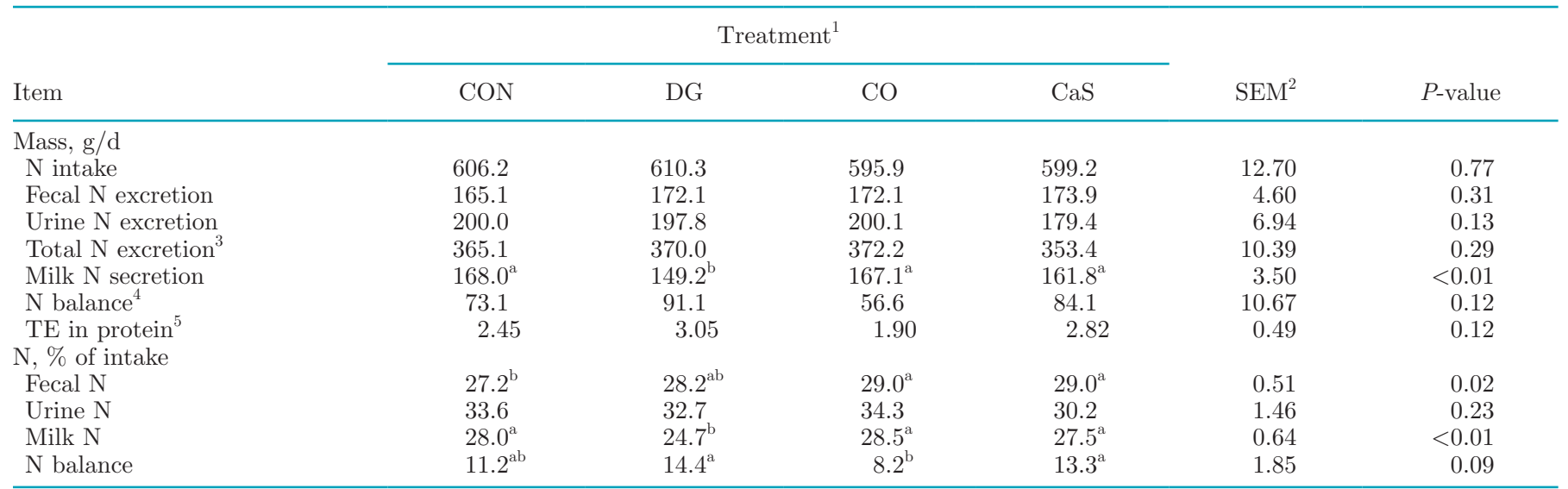

\footnotetext{
${ }^{\mathrm{a}, \mathrm{b}}$ Means within a row with different superscripts differ $(P<0.05)$.

${ }^{1}$ Treatments: $\mathrm{CON}=$ control; $\mathrm{DG}=$ reduced-fat dried distillers grains and solubles; $\mathrm{CO}=\mathrm{DG}$ plus corn oil; and CaS $=\mathrm{DG}$ plus calcium sulfate.

${ }^{2}$ Lowest $\mathrm{SE}$ of treatment means is listed.

${ }^{3}$ Total $\mathrm{N}$ excretion $=$ fecal $\mathrm{N}+$ urine $\mathrm{N}$.

${ }^{4}$ Nitrogen balance $=$ intake $\mathrm{N}-$ fecal $\mathrm{N}-$ urine $\mathrm{N}-$ milk $\mathrm{N}$.

${ }^{5} \mathrm{TE}=$ tissue energy.
}

solely for the purpose of providing specific information and does not imply recommendation or endorsement by the USDA. USDA is an equal opportunity provider and employer.

\section{REFERENCES}

Abdelqader, M. M., A. R. H. Ippen, K. F. Kalscheur, D. J. Schingoethe, and A. D. Garcia. 2009. Isolipidic additions of fat from corn germ, corn distillers grains, or corn oil in dairy cows diets. J. Dairy Sci. 92:5523-5533.

AOAC International. 2000. Official Methods of Analysis. Vol. 1 and 2. 17th ed. AOAC International, Gaithersburg, MD.

AOAC International. 2006. Official Methods of Analysis. 18th ed. AOAC International, Gaithersburg, MD.

Beauchemin, K. A., M. Kreuzer, F. O'Mara, and T. A. McAllister 2008. Nutritional management for enteric methane abatement: A review. Aust. J. Exp. Agric. 48:21-27.

Beauchemin, K. A., S. M. McGinn, and H. Petit. 2007. Methane abatement strategies for cattle: lipid supplementation of diets. Can. J. Anim. Sci. 87:431-440.

Benchaar, C., F. Hassanat, R. Gervais, P. Y. Chouinard, C. Julien, H. V. Petit, and D. I. Massé. 2013. Effects of increasing amounts of corn dried distillers grains with solubles in dairy cow diets on methane production, ruminal fermentation, digestion, $\mathrm{N}$ balance, and milk production. J. Dairy Sci. 96:2413-2427.

Birkelo, C. P., M. J. Brouk, and D. J. Schingoethe. 2004. The energy content of wet corn distillers grains for lactating dairy cows. J. Dairy Sci. 87:1815-1819.

Blaxter, K. L. 1962. The Energy Metabolism of Ruminants. 2nd ed. Hutchinson \& Co. Ltd., London, UK.

Boston, R. C., D. G. Fox, C. J. Sniffen, R. Janczewski, R. Munsen, and W. Chalupa. 2000. The conversion of a scientific model describing dairy cow nutrition and production to an industry tool: The CPM Dairy project. Pages 361-377 in Modelling Nutrient Utilization in Farm Animals. J. P. McNamara, J. France, and D. Beever, ed. CABI Publishing, Oxford, UK.

Brouwer, E. 1965. Report of sub-committee on constants and factors. Pages 441-443 in Energy Metabolism. K. L. Blaxter, ed. Euro- pean Association for Animal Production Publication No. 11, Ayr Scotland.

Castillo-Lopez, E., H. A. Ramirez Ramirez, T. J. Klopfenstein, D. Hostetler, K. Karges, S. C. Fernando, and P. J. Kononoff. 2014. Ration formulations containing reduced-fat dried distillers grains with solubles and their effect on lactation performance, rumen fermentation, and intestinal flow of microbial nitrogen in Holstein cows. J. Dairy Sci. 97:1578-1593.

Chase, L. E. 2014. Carbon footprint and the dairy industry. Cornell Nutrition Conference Animal Science Conference Proceedings. Cornell University, Ithaca, NY.

Coppock, C. E. 1985. Energy nutrition and metabolism of the lactating dairy cow. J. Dairy Sci. 68:3403-3410.

Coppock, C. E., W. P. Flatt, and L. A. Moore. 1964. Effect of hay to grain ratio on utilization of metabolizable energy for milk production by dairy cows. J. Dairy Sci. 47:1330-1338.

Dong, L. F., C. P. Ferris, D. A. McDowell, and T. Yan. 2015. Effects of diet forage proportion on maintenance energy requirement and the efficiency of metabolizable energy use for lactation by lactating dairy cows. J. Dairy Sci. 98:8846-8855.

DRMS. 2014. DHI Glossary. Dairy Records Management System, Raleigh, NC.

Environmental Protection Agency. 2010. Methane and nitrous oxide emissions. US Environmental Protection Agency, Washington, DC.

EPA (US Environmental Protection Agency). 1994. Method 200.7. Determination of metals and trace elements in water and wastes by inductively coupled plasma-atomic emission spectrometry. Revision 4.4. Accessed Sep. 29, 2017. http://www.epa.gov/sam/pdfs/ EPA-200.7.pdf.

Ferrell, C. L., and J. W. Oltjen. 2008. ASAS Centennial paper: Net energy systems for beef cattle- Concepts, applications, and future models. J. Anim. Sci. 86:2779-2794.

Foth, A. J., T. Brown-Brandl, K. J. Hanford, P. S. Miller, G. Garcia Gomez, and P. J. Kononoff. 2015. Energy content of reduced-fat dried distillers grains with solubles for lactating dairy cows. J. Dairy Sci. 98:7142-7152.

Freetly, H. C., J. A. Nienaber, and T. Brown-Brandl. 2006. Partitioning of energy during lactation of primiparous beef cows. J. Anim. Sci. 84:2157-2162.

Gill, M., P. Smith, and J. M. Wilkinson. 2010. Mitigating climate change: The role of domestic livestock. Animal 4:323-333. 
Goering, H. K., and P. J. Van Soest. 1970. Forage Fiber Analysis. USDA Agricultural Research Service. Handbook number 379. U.S. Dept. of Agriculture. Superintendent of Documents, US Government Printing Office, Washington, DC.

Grainger, C., C. W. Holmes, and Y. F. Moore. 1985. Performance of Friesian cows with high and low breeding indexes. Anim. Prod. 40:389-400.

Hales, K. E., A. P. Foote, T. M. Brown-Brandl, and H. C. Freetly. 2017. The effects of feeding increasing concentrations of corn oil on energy metabolism and nutrient balance in finishing beef steers. J. Anim. Sci. 95:939-948.

Hall, M. B. 2009. Analysis of starch, including maltooligosaccharides, in animal feeds: A comparison of methods and a recommended method for AOAC collaborative study. J. AOAC Int. 92:42-49.

Heinrichs, A. J., and P. J. Kononoff. 2002. Evaluating particle size of forages and TMRs using the New Penn State Forage Particle Separator. Tech. Bull. DAS 02-42. College Agric. Sci., Cooperative Ext., Pennsylvania State University, University Park, PA.

Huhtanen, P., M. Rinne, and J. Nousiainen. 2009. A meta-analysis of feed digestion in dairy cows. 2 . The effects of feeding level and diet composition on digestibility. J. Dairy Sci. 92:5031-5042.

Hynes, D. N., S. Stergiadis, A. Gordon, and T. Yan. 2016. Effects of concentrate crude protein content on nutrient digestibility, energy utilization, and methane emissions in lactating dairy cows fed fresh-cut perennial grass. J. Dairy Sci. 99:8858-8866.

Innovation Center for US Dairy. 2009. Dairy Industry Applauds White House Strategy for Methane Emissions Reduction. News Release. Accessed Nov. 1, 2017. http://www.nmpf.org/files/White-House -Methane-Emissions-Reduction-032814.pdf.

IPCC. 2013. Fifth Assessment Report - Climate Change. Accessed Jul. 18, 2018. http://www.ipcc.ch/report/ar5/wg1/.

Janicek, B. N., P. J. Kononoff, A. M. Gehman, and P. H. Doane. 2008. The effect of feeding dried distillers grains plus solubles on milk production and excretion of urinary purine derivatives. J. Dairy Sci. 91:3544-3553.

Johnson, K. A., and D. E. Johnson. 1995. Methane emissions from cattle. J. Anim. Sci. 73:2483-2492.

Knapp, J. R., G. L. Laur, P. A. Vadas, W. P. Weiss, and J. M. Tricarico. 2014. Invited review: Enteric methane in dairy cattle production: Quantifying the opportunities and impact of reducing emissions. J. Dairy Sci. 97:3231-3261.

Kononoff, P. J., and K. J. Hanford. 2006. Technical note: Estimating statistical power of mixed models used in dairy nutrition experiments. J. Dairy Sci. 89:3968-3971.

McGinn, S. M., Y. H. Chung, K. A. Beauchemin, A. D. Iwaasa, and C. Grainger. 2009. Use of corn distillers' dried grains to reduce enteric methane loss from beef cattle. Can. J. Anim. Sci. 89:409-413.

Moe, P. W., and H. F. Tyrrell. 1971. Net energy value for lactation of high- and low- protein diets containing corn silage. J. Dairy Sci. 55:288-303.

Moraes, L. E., E. Kebreab, A. B. Strathe, J. Dijkstra, J. France, D. P. Casper, and J. G. Fadel. 2015. Multivariate and univariate analysis of energy balance data from lactating dairy cows. J. Dairy Sci. 98:4012-4029.

Nagaraja, T. G., C. J. Newbold, C. J. Van Nevel, and D. I. Demeyer. 1997. Manipulation of ruminal fermentation. Pages 523-632 in The Rumen Microbial Ecosystem. P. N. Hobson and C. S. Stewart, ed. Chapman and Hall, London, UK.

NRC. 2001. Nutrient Requirements of Dairy Cattle. 7th rev. ed. Natl. Acad. Press, Washington, DC.

NRC. 2005. Mineral Tolerance of Animals. Vol. 2nd rev. ed. Natl. Acad. Press, Washington, DC.

Nienaber, J. A., and A. L. Maddy. 1985. Temperature controlled multiple chamber indirect calorimeter-design and operation. Trans. ASAE 28:555-560.

Nkrumah, J. D., E. K. Okine, G. W. Mathison, K. Schmid, C. Li, J. A Basarab, M. A. Price, Z. Wang, and S. S. Moore. 2006. Relationships of feedlot feed efficiency, performance, and feeding behavior with metabolic rate, methane production, and energy partitioning in beef cattle. J. Anim. Sci. 84:145-153.

Olijhoek, D. W., A. L. F. Hellwing, M. Brask, M. R. Weisbjerg, O. Højberg, M. K. Larsen, J. Dijkstra, E. J. Erlandsen, and P. Lund. 2016. Effect of dietary nitrate level on enteric methane production, hydrogen emission, rumen fermentation, and nutrient digestibility in dairy cows. J. Dairy Sci. 99:6191-6205.

Ramirez Ramirez, H. A., E. Castillo Lopez, K. J. Harvatine, and P. J. Kononoff. 2015. Fat and starch as additive risk factors for milk fat depression in dairy diets containing corn dried distillers grains with solubles. J. Dairy Sci. 98:1903-1914.

Roseler, D. K., J. D. Ferguson, C. J. Sniffen, and J. Herrema. 1993. Dietary protein degradability effects on plasma and milk urea nitrogen and milk nonprotein nitrogen in Holstein cows. J. Dairy Sci. $76: 525-534$.

Schingoethe, D. J., K. F. Kalscheur, A. R. Hippen, and A. D. Garcia. 2009. Invited review: The use of distillers products in dairy cattle diets. J. Dairy Sci. 92:5802-5813.

Tamura, T., H. Nakamura, S. Sato, M. Seki, and H. Nishiki. 2014. A modified catheterization procedure to reduce bladder damage when collecting urine samples from Holstein cows. J. Vet. Med. Sci. 76:819-826.

Thoma, G., J. Popp, D. Nutter, D. Shonnard, R. Ulrich, M. Matlock, D. S. Kim, Z. Neiderman, N. Kemper, C. East, and F. Adom. 2013. Greenhouse gas emissions from milk production and consumption in the United States: A cradle-to-grave life cycle assessment circa 2008. Int. Dairy J. 31:S3-S14.

van Knegsel, A. T. M., H. van den Brand, J. Dijkstra, W. M. van Straalen, M. J. W. Heetkamp, S. Tamminga, and B. Kemp. 2007. Dietary energy source in dairy cows in early lactation: Energy partitioning and milk production. J. Dairy Sci. 90:1467-1476.

Van Soest, P. J., J. B. Robertson, and B. A. Lewis. 1991. Methods for dietary fiber, neutral detergent fiber, and nonstarch polysaccharides in relation to animal nutrition. J. Dairy Sci. 74:3583-3597.

van Zijderveld, S. M., J. Dijkstra, H. B. Perdok, J. R. Newbold, and W. J. J. Gerrits. 2011. Dietary inclusion of diallyl disulfide, yucca powder, calcium fumarate, an extruded linseed product, or medium-chain fatty acids does not affect methane production in lactating dairy cows. J. Dairy Sci. 94:3094-3104.

van Zijderveld, S. M., W. J. J. Gerrits, J. A. Apajalahti, J. R. Newbold, J. Dijkstra, R. A. Leng, and H. B. Perdok. 2010. Nitrate and sulfate: Effective alternative hydrogen sinks for mitigation of ruminal methane production in sheep. J. Dairy Sci. 93:5856-5866.

Vermorel, M., B. Remond, J. Vernet, and D. Liamadis. 1982. Utilization of body reserves by high-producing cows in early lactation; effects of crude protein and amino-acid supply. Pages 18-21 in Energy Metabolism of Farm Animals. A. Ekern and F. Sundstøl, ed. European Association for Animal Production Publication No. 29, Ås, Norway.

Weiss, W. P., L. B. Willett, N. R. St-Pierre, D. C. Borger, T. R. McKelvey, and D. J. Wyatt. 2009. Varying forage type, metabolizable protein concentration, and carbohydrate source affects manure excretion, manure ammonia, and nitrogen metabolism of dairy cows. J. Dairy Sci. 92:5607-5619.

Wildman, E. E., G. M. Jones, P. E. Wagner, R. L. Boman, H. F, Troutt, and T. N. Lesch. 1982. A dairy cow body condition scoring system and its relationship to selected production characteristics. J. Dairy Sci. 65:495-501.

Xue, B., T. Yan, C. F. Ferris, and C. S. Mayne. 2011. Milk production and energy efficiency of Holstein and Jersey-Holstein crossbred dairy cows offered diets containing grass silage. J. Dairy Sci. 94:1455-1464.

Yan, T., F. J. Gordon, R. E. Agnew, M. G. Porter, and D. C. Patterson. 1997. The metabolisable energy requirement for maintenance and the efficiency of utilization of metabolisable energy for lactation by dairy cows offered grass silage-based diets. Livest. Prod. Sci. 51:141-150. 